\title{
Az inzulinrezisztencia valós és téves értelmezése a klinikai gyakorlatban
}

\author{
Winkler Gábor dr. ${ }^{1,2}$ \\ ${ }^{1}$ Észak-Közép-budai Centrum, Új Szent János Kórház és Szakrendelő, II. Belgyógyászat-Diabetológia, Budapest \\ ${ }^{2}$ Miskolci Egyetem, Egészségügyi Kar, Miskolc
}

\begin{abstract}
Az inzulinrezisztencia (IR) fennállásának megerősítése vagy kizárása a hazai diabetes-szakrendelésekre irányított nem cukorbetegek egyik leggyakoribb beutalási indoka. A közlemény áttekinti az IR fogalmát, kórélettani jelentőségét, kórismézési lehetőségeit és kezelési vonatkozásait. Kiemeli, hogy az inzulinhatás csökkenése számos betegség kísérőjelensége, s önmagában, más tünetek nélkül nem igényli részletes kivizsgálását. Ha mégis felmerül, tájékozódó céllal elegendő a HOMA-IR-érték számítása, valamint az éhomi vércukor- és széruminzulinszint meghatározása. Ha valamely társbetegség részeként igazolódik, annak komplex kezelése szükséges.
\end{abstract}

Orv Hetil. 2020; 161(26): 1088-1093.

Kulcsszavak: inzulinrezisztencia, vizsgálati módszerek, HOMA-IR, kezelés

\section{Real and misinterpretation of insulin resistance in the clinical practice}

Confirming or ruling out the presence of insulin resistance (IR) is one of the most common reasons for referral to non-diabetics in Hungary for diabetes outpatient units. The article overviews the concept of IR, its importance in pathophysiology, the diagnostic capabilities, and its treatment implications. It emphasizes that the decline in insulin activity is a co-morbidity of many diseases and does not, in itself, require detailed examination without other symptoms. If this occurs, it is sufficient to calculate the HOMA-IR value and determine fasting blood glucose and serum insulin levels for information purposes. If it is confirmed as part of a comorbid condition, complex treatment is required.

Keywords: insulin resistance, diagnostic tools, HOMA-IR, treatment

Winkler G. [Real and misinterpretation of insulin resistance in the clinical practice]. Orv Hetil. 2020; 161(26): $1088-1093$.

(Beérkezett: 2020. február 13.; elfogadva: 2020. március 19.)

\begin{abstract}
Rövidítések
$\mathrm{BMI}=($ body mass index $)$ testtömegindex; CRP $=$ C-reaktív protein; FIRI = (fasting IR index) éhomi IR-index; FPG = (fasting plasma glucose) éhomi vércukor; FPI = (fasting plasma insulin) éhomi széruminzulin; FSIVGTT = (frequent sampling intravenous glucose tolerance test) gyakori mintavételü intravénás glükóztolerancia-teszt; $\mathrm{HbA}_{\mathrm{lc}}=$ hemoglobin- $\mathrm{A}_{\mathrm{lc}} ; \mathrm{HDL}$ = (high-density lipoprotein) magas sűrüségű lipoprotein; HEGC = hyperinsulinaemiás euglykaemiás glükóz 'clamp'; HOMA-IR = (homeostatic model assessment of insulin resistance) az éhgyomri vércukor- és inzulinszintértékekből kiszámolt matematikai modellszám; hsCRP $=$ (highly sensitive CRP) nagy érzékenységű CRP; IGF-BP = (insulin-like growth factor-binding protein) inzulinszerú növekedési faktort kötő
\end{abstract}

fehérje; IR = (insulin resistance) inzulinrezisztencia; $\mathrm{LDL}=$ (low-density lipoprotein) alacsony sürüségű lipoprotein; OGTT $=$ (oral glucose tolerance test) oralis cukorterhelés; PCOS = polycystás ovarium szindróma; QUICKI = (quantitative insulin sensitivity check index) kvantitatív inzulinérzékenységi index, az inzulinrezisztencia egyik modellszáma; $\mathrm{TNF}=$ tumornekrózis-faktor

Az inzulinrezisztencia (IR) fennállásának megerősítése vagy kizárása a hazai diabetes-szakrendelésekre irányított nem cukorbetegek egyik leggyakoribb beutalási indoka. A legtöbbször nőgyógyászati rendelések kezdeményezik a meddőség, a vérzészavarok, ritkábban a spontán veté- 
lések lehetséges okát keresve vagy polycystás ovarium szindróma (PCOS) miatt, de mind gyakoribb az igény bőrgyógyászati okból - visszatérő acnék, hajhullás -, illetve háziorvosok részéről, remélve, hogy igazolása megerôsíti az érintett személyben a túlsúly/elhízás miatt szükséges életmódváltás indokoltságát. Egyre többször fordul elő az is, hogy a páciensek kezdeményezik a vizsgálatát, indokot keresve különböző egészségügyi problémáikra.

Se szeri, se száma az ilyen okokból indikált laboratóriumi vizsgálatoknak, a különböző tartamú és mintavételgyakoriságú terheléses eljárásoknak, inzulin-, $\mathrm{HbA}_{1 c^{-}}$ meghatározásoknak és az „első számú slágerré” vált HOMA- (pontosabban, bár nem így használják, a HOMA-IR-) számítás kérésének. Bár az elmúlt években a hazai szakirodalom is részletesen foglalkozott a kérdéskörrel $[1,2]$, a napi gyakorlat segítését szem előtt tartva indokoltnak látszik ismételt áttekintése.

\section{Az inzulinrezisztencia fogalma, kórélettani jelentősége}

A legáltalánosabb meghatározás szerint az IR az az állapot, amikor az inzulin egy vagy több hatása az élettanitól elmarad, azaz kvantitatíve normális inzulinválasz csak a fiziológiásnál nagyobb mennyiségú inzulin jelenlétében figyelhetô meg. Más megfogalmazással a hormon csökkent biológiai aktivitása elsődleges célszövetein, a vázizomzaton, a májon és a zsírszöveten [3]. Mivel a hormon számos - proliferációt, sejtnövekedést segítő, illetve anyagcsere- - hatása közül a legjobban a szénhidrátanyagcserét érintő́k mérhetők, a gyakorlat számára az IR az inzulin eredményezte vércukorcsökkenés normálistól való elmaradását jelenti [1].

Ezen általánosabb érvényư megfogalmazással jó ideje érvényét veszítette az a különböző forrásokban még ma is fellelhető korábbi meghatározás, amely az IR-t - diabetes fennállása esetén - extrém nagy, napi 200 egységet meghaladó inzulinszükséglettel jellemezte. Ennek hangsúlyozása azért szükséges, mert IR egyrészt a nem cukorbetegeken is kialakulhat - amint arra később még visszatérünk -, másrészt a mértéke változó.

Az IR heterogén megjelenésú állapot. Az inzulinhatás csökkenése egyes életszakaszok - pubertás, a várandósság második-harmadik trimesztere, időskor - kísérójelensége, de contrainsularis hatások eredményeként napszakosan is megfigyelhető, például hajnali $4-5$ óra között, majd a délelótt első felében. Kórosnak akkor tekinthetô, ha mértéke a fiziológiásat meghaladó (ez figyelhető meg például gestatiós diabetesben), vagy a kiváltó ok megszúnése után is fennmarad. Lehet genetikai eredetú (a receptorszám vagy -múködés mutáción alapuló károsodása), veleszületett (például intrauterin retardatio következménye), a leggyakoribb formái azonban szerzetten kialakulók. Jelentós IR alakul ki az úgynevezett „speciális diabetesformák” közé tartozó, B-típusú inzulinreceptor-károsodással járó kórkép esetében is, amely során inzulinreceptor-ellenes antitestek alakulnak ki az autoimmunitás egyéb klinikai és laboratóriumi tünetei mellett [4].

$\mathrm{Az}$ állapot biokémiai háttere, az inzulinreceptor jelátviteli folyamatai és az ezeket zavaró molekuláris mechanizmusok kapcsolata ma már számos vonatkozásában fel van tárva. Részletes áttekintésük meghaladja jelen munkánk kereteit. E vonatkozások, valamint a károsodások prereceptor-, receptor-, illetve posztreceptorformáinak részletezése tekintetében összefoglaló munkákra utalunk $[1,2]$.

Az inzulinhatás változása adaptációs folyamatok része. Így például a gestatio kezdetén az inzulinérzékenység fokozódik, ami segíti a fetus biztonságos fejlődéséhez szükséges anyai zsírtartalékok növekedését, ugyanakkor a második-harmadik trimesztert az anyai szervezet „facilitált éhezése”, a lipolízis fokozódása, a magzatét a „facilitált anabolizmus" jellemzi. Ez segíti, hogy az utóbbi fejlődése és növekedése az elérhető legoptimálisabb lehessen [5]. Hasonló adaptáció figyelhetô meg jelentős fizikai terhelés alatt, majd befejeződését követően, vagy az alvás-ébrenlét periódusok váltakozása során.

\section{Az inzulinhatás megítélését szolgáló mérőszámok és mutatók}

Kutatási célok számára az inzulinhatás, -érzékenység megítélésére a hyperinsulinaemiás euglykaemiás glükóz 'clamp' (HEGC) az arany standardnak tekintett eljárás. Magas költsége, humánerö- és anyagigénye folytán azonban alkalmazása a rutin klinikai gyakorlat számára nem jön szóba $[6,7]$. A kiváltására mért paraméterek (éhomi vércukor- és széruminzulinszint, CRP), valamint az ezekből számított modell- (HOMA-IR, QUICKI), illetve viszonyszámok (inzulinogén index, glükóz/inzulin hányados, éhomi IR-index), továbbá terheléses eljárások (például oralis cukorterhelés [OGTT], gyakori mintavételû intravénás glükóztolerancia-teszt [FSIVGTT]) során közvetlenül nyert vagy származtatott adatok szolgálják az inzulinhatás becslését.

Az FSIVGTT ugyancsak nem a napi gyakorlat körébe tartozó eljárás. Előnyét jelenti ugyanakkor, hogy elvégzése a béta-sejt-múködés és az inzulinhatás megítélését egyaránt segíti.

A fentiek közül egyszerúsége folytán a HOMA-IR vált a legszélesebb körben alkalmazottá. A Matthews és munkatársai által 1985-ben leírt eredeti változatban a mmol/l-ben kifejezett éhomi vércukor (FPG)- és a mIU/l-ben megadott éhomi széruminzulin (FPI)-szint szerepelt, a következő képlet szerint: HOMA-IR $=($ FPG $\times$ FPI $: 22,5$. Meghatározták az inzulinszekréció modellszámítását is: HOMA-B\% $=(\mathrm{FPI} \times 20):(\mathrm{FPG}-3,5)$ [7].

Mindkét mutató jó korrelációt jelzett a már említett HEGC, illetve FSIVGTT értékeivel, ezért mind epidemiológiai elemzésekben, mind követéses vizsgálatokban jól alkalmazhatónak bizonyultak. Idővel azonban felme- 
rültek olyan megfontolások, amelyek a számítások pontosabbá tételét indokolták. Ilyen volt, hogy az inzulinelválasztás, mint valamennyi hormonunké, pulzatilis természetű, ezért az FPI-szintet helyesebb 15 perces intervallumban levett két minta átlaga alapján meghatározni. Ugyanígy, az alapmodell nem vette figyelembe a hepaticus glükózkibocsátás oszcillálását, valamint a szöveti glükózfelvétel módosulásait. Ezért 1996-ban új, komputer generálta modell készült, amely a HOMA2-IR, illetve HOMA2-B\% nevet, a korábbi változatnak egyidejüleg HOMAl-IR, illetve HOMAl-B\% átnevezése mellett [7, 8]. A két mérőszám összevetésével számos vizsgálatot végeztek, s mivel jelentős eltérés nem mutatkozott közöttük, viszont az új változat lényegesen időigényesebb és jártasságot igénylő volt, a klinikai gyakorlatban az új számítás nem terjedt el [9]. Megmaradt a korábbi HOMA-IR és HOMA-B\% jelzés is, munkánkban is így szerepel a továbbiakban. Ha a képletekben szereplő paraméterek más mértékegységben $(\mathrm{mg} / \mathrm{dl}$, illetve pmol/1, $\mu \mathrm{IU} / \mathrm{l}$ ) vannak megadva, átszámítást kell végezni!

Hosszú időn keresztül tartotta magát az a nézet, hogy a HOMA-IR a >4,0 érték esetén tekinthető biztosan kórosnak. $S$ bár kétségtelen, hogy értékét számos tényező - etnikum, nem, életkor, rendszeres fizikai aktivitás - befolyásolja [10-12], nagy esetszámú népességi felmérések bizonyították, hogy normális értéke ennél jóval alacsonyabb.

Egy 3539, középkorú személyt magában foglaló csehországi felmérésben vizsgálták anyagcsere-egészséges, praediabeteses és cukorbeteg személyek anyagcsere-mutatóit. Az átlagos HOMA-IR-érték 1,47, 2,17, illetve 3,49 volt. Mindkét nemben a $\geq 3,86$-os értéket találták a diabeteskockázat legnagyobb érzékenységű prediktorának. A megfigyelés értékét csökkenti, hogy a testtömegindex (BMI) mindhárom csoportban obesitast jelző volt $\left(31,6,35,04\right.$, illetve $\left.37,81 \mathrm{~kg} / \mathrm{m}^{2}\right)$, a három csoport mintaszáma jelentősen eltért egymástól (1947, 1459, illetve 133), valamint a HOMA-IR prediktív értékének meghatározásakor a nem cukorbeteg és a praediabeteses csoportot együtt értékelték. Az adatok azonban jól szemléltetik, hogy az IR-t jelző HOMA-érték a korábbi határnál bizonyosan alacsonyabb [13].

$\mathrm{Az}$ adatok többsége azt támasztja alá, hogy felnőttek esetében a >2,5 érték tekinthető a csökkent inzulinhatás „cut-off” pontjának, bár egységes nemzetközi irányelv e tekintetben jelenleg nem ismert [14-17]. Nincs ajánlásszintû állásfoglalás a mesterséges megtermékenyítés kapcsán meghatároztatott - hazánkban ma oly gyakran kért - HOMA-IR-érték tekintetében sem [18], s ilyen nemzetközi vizsgálat sem ismert [19].

Ez idő szerint nincs egységes álláspont a serdülőkorúak még normálisnak tekinthető HOMA-IR-értéke tekintetében sem. Egyes szerzők korspecifikus referenciaértékeket dolgoztak ki $[20,21]$, de a „cut-off” értékek vonatkozásában továbbra is igen megoszló a szakirodalom.

A HOMA-IR mellett széles körben használt az inzulinszintmérésekkel kiegészített glükóztolerancia-vizsgá- lat is. A szóba jövő módszerek közül az OGTT egyszerüen kivitelezhető, végzése és értékelése jól standardizált, az FSIVGTT azonban a vizsgált személy számára megterhelő, emellett nagyobb humánerő- és anyagráfordítást igényel. A napi klinikai munkában ezért nem használatos, alkalmazására elsősorban tudományos céllal kerül sor.

Hangsúlyozni szükséges, hogy ha az OGTT-t a szénhidrát-anyagcsere megítélése céljából végzik, akkor nem szükséges az inzulin (még kevésbé a C-peptid) szintjének vizsgálata. Az inzulinszint meghatározása - terheléses vizsgálat során - szimptómás hypoglykaemia okának felderítése céljából jöhet szóba. Önmagában az IR tisztázása nem igényli a széruminzulinszint több időpontban történő mérését. Csak a teljesség kedvéért rögzítjük, hogy ismert cukorbetegen az OGTT végzése ellenjavallt.

Az Egészségügyi Világszervezet és a Nemzetközi Diabetes Szövetség irányelve [22], valamint ehhez igazodóan a cukorbetegség kórismézésével és kezelésével kapcsolatos hazai módszertani ajánlás [23] a diabetes és elóállapotai kórismézésére két - éhomi (0. perces) és a terhelés 120. percében történő - vércukorvizsgálatot javasol. Terhességben újabban használatos a 60 perces minta is $[23,24]$.

Ha a vizsgálatot mégis IR igazolása céljából indikálják, az inzulinszint mérésére általában a 0-30-60. percben kerül sor; a hypoglykaemia kivizsgálásakor használják a 120. és 180. percben történő meghatározást is. Nincs konszenzus abban a tekintetben, hogy - ha végeztetésére sor kerül - OGTT alkalmával hány és milyen időközönkénti vérvételre kerüljön sor inzulinszintmérés céljából. Ismertek táblázatok az egyes időpontokban mért inzulinszint normálértékei tekintetében (1. táblázat) $[25,26]$, de a referenciaértékek széles tartományban mozognak (és például a 90 perces értékről nem találtam adatot).

Éppen az értékek tág tól-ig tartománya folytán próbálkoztak korábban a kóros állapotot az FPI-szint >3-5-szörös emelkedésében meghatározni, de a gyakorlat nem vált általánossá. Egy vizsgálatban, amelyben az inzulinszintnek mint biomarkernek a keringési kockázatot, illet-

\begin{tabular}{l|cc} 
1. táblázat & $\begin{array}{l}\text { Az inzulinszintek referenciaértékei oralis glükózterhelés során } \\
{[25,26] \text {. A normális éhomi tartomány a választott módszer }} \\
\text { függnényében eltérhet. A mIU/1-érték SI-egységben történó } \\
\text { kifejezésének konverziós faktora } \times 6,945\end{array}$ \\
\hline Idôpont & $\begin{array}{c}\text { Inzulinszint } \\
\mathrm{mIU} / 1\end{array}$ & $\begin{array}{c}\text { pmol/1 értékben } \\
\text { megadva }\end{array}$ \\
\hline Éhomra & $<25$ & $<174$ \\
A terhelés 30. percében & $30-230$ & $208-1597$ \\
A terhelés 60. percében & $180-276$ & $125-1917$ \\
A terhelés 90. percében & $\mathrm{n} . \mathrm{a}$. & $\mathrm{n} . \mathrm{a}$. \\
A terhelés 120. percében & $16-166$ & $111-1153$ \\
A terhelés 180. percében & $<25$ & $<174$
\end{tabular}

n. a. $=$ nincs adat 
ve a praediabetest jelző értékét elemezték, azt találták, hogy e tekintetben az éhomi és a csúcsinzulinszint együttes elemzése a legcélravezetőbb. Az éhomi inzulinszint 30-50 $\mu \mathrm{U} / \mathrm{ml}$ közötti értékét határesetnek, a $\geq 50$ $\mu \mathrm{U} / \mathrm{ml}-\mathrm{t}$ biztosan kórosnak értékelték. Használható markernek találták a postprandialis inzulinszintet is, de a vizsgáltak között eltérés mutatkozott abban, hogy a csúcsérték a 60. percben vagy később jelentkezett [27]. Egy másik vélemény szerint a magas FPI-szint és a normális OGTT-eredmény ugyancsak IR-t jelez [6].

Összetettebb számítást igénylő, de a HOMA-IR-értéknél nagyobb prediktív erővel rendelkező, az arany standard módszerrel szorosabban korreláló mutató az ún. QUICKI, amelyet az FPI-szint $(\mu \mathrm{E} / \mathrm{ml})$ és az FPGszint $(\mathrm{mg} / \mathrm{dl})$ ismeretében lehet meghatározni: [1 : (log inzulin $)+(\log$ glükóz) $]$. Normálértéke <0,357 [6]. A normális széruminzulinszint változó referenciatartománya folytán minden laboratóriumnak meg kell határoznia a saját normálértékét.

Az IR további mutatói - Matsuda-, Gutt-, Stumvoll-, Avignon-index - nem terjedtek el a klinikai gyakorlatban. Az egyszerúen számítható éhomi IR-index (FIRI fasting IR index: éhomi vércukor $[\mathrm{mmol} / \mathrm{l}] \times$ éhomi inzulin $[\mu \mathrm{U} / \mathrm{ml}])$, valamint az éhomi vércukor/inzulin hányados nem váltotta be a hozzá füzött reményeket [6]. Az inzulinogén index a béta-sejt-múködés megítélésére szolgál.

Látótérbe kerültek további paraméterek is. Ilyen az inzulinszerű növekedési faktort (IGF-et) kötő fehérje (BP), a makrofág szolúbilis CD36-fehérje, a ferritin, valamint a nagy érzékenységú C-reaktív protein (hsCRP). Ezek vizsgálata az utóbbi kivételével - speciális reagenskészletet igénylő voltuk folytán - egyelőre nem vált széles körúvé, s kellő számú adattal az sincs alátámasztva, hogy a jelenleg használatosaknál megbízhatóbb mérōszámok lehetnek-e az IR felismerésére. A citokinek - TNF-rendszer, adiponektin, rezisztin - és a transzkripciós faktorok - C3a desArg - közül többnek az összefüggését igazolták az inzulinérzékenységgel. Meghatározásuk egyelőre ugyancsak nem a napi gyakorlat része [6].

Az akutfázis-fehérjék közé tartozó CRP széles körben használt mutató - elsősorban bakteriális eredetű - gyulladások felismerésére és követésére. Értéke $>5,0$ esetén tekinthető kórosnak. A hsCRP-meghatározás érzékenyebb eljárás, de elve az előzőével azonos, csak más kalibrációval történik. Ma elsősorban a keringési kockázat egyik markereként használjuk. Közepes kockázatot jelez 1,0-3,0 mg/1, nagy kockázatot $\geq 3,0 \mathrm{mg} / 1$ esetén. A Bogalusa Heart Studyban azt találták, hogy emelkedése megelőzte a HOMA-IR hasonló változását [28]. Egy másik vizsgálatban azt találták, hogy $>3,0 \mathrm{mg} / 1$ értéke korrelált a BMI-vel és az IR HOMA alapján számított értékével [29]. Az irodalmi adatokból ugyanakkor az is megállapítható, hogy még nem alakult ki egységes álláspont az inzulinérzékenység már biztosan kóros voltát jelző értékének vonatkozásában. Értékét számos társtényező (életkor, nem, BMI, vérzsírtükör) is befolyásolja.

\section{Az inzulinrezisztencia klinikai megjelenési formái}

Önmagában az IR nem okoz klinikai panaszokat vagy tüneteket. Számos olyan állapot ismert azonban, amelyeknek az IR a kísérőjelensége lehet. Ezek közé tartozik, a teljesség igénye nélkül: obesitas, diabetes mellitus és elő́llapotai, dyslipidaemia (alacsony HDL-, emelkedett LDL-koleszterin- és/vagy trigliceridszint), PCOS, hypertonia, hormonális betegségek (acromegalia, hypercorticismus, hyper- és hypothyreosis, hyperandrogenismus stb.), hypercoagulabilitas (emelkedett plazminogénaktivátor-1-szinttel járó állapotok), nem alkoholos és alkoholos zsírmáj [30]. A felsorolt állapotok klinikai jellemzőik alapján rendszerint könnyen felismerhetők, és az IR rutinszerü vizsgálatára nincs szükség.

A bőrgyógyászati okok között az acanthosis nigricans és az IR kapcsolata a legismertebb. Ez a bőrnek a változó kiterjedésű, a legtöbbször a nyakon-válltájékon vagy a törzsön jelentkező, az esetek egy részében fokozott szőrnövekedéssel is társuló, barnásszürke elváltozása. Gyakran megelőzi a 2-es típusú diabetes megjelenését. Hátterében az esetek egy részében A-típusú inzulinreceptor-károsodás áll $[30,31]$. Más bőrgyógyászati megbetegedés - például acne, psoriasis, androgén alopecia, vitiligo - is társulhat IR-val. Az összefüggés biokémiai háttere nem minden esetben tisztázott [31].

Számos veleszületett betegség kísérőjelensége az IR Alstrom-, Werner-, Rabson-Mendenhall-szindróma, dystrophia myotonica stb. -, ezek azonban a klinikai kép alapján felismerhetők, s kórismézésük az IR meghatározása nélkül is megvalósítható.

\section{Milyen esetekben lehet indokolt az inzulinrezisztencia célzott keresése?}

Az előző felsorolás meggyőzően alátámasztja, hogy az IR számos állapot és megbetegedés átmeneti (például gyulladás, égés stb.) vagy tartós kísérőjelensége lehet, de - kevés kivételtől eltekintve - az inzulinhatás célzott vizsgálatára nincs szükség.

A HOMA-IR meghatároztatására napjaink gyakorlatában a legtöbbször a meddőség kivizsgálásakor, PCOS kórismézésekor vagy bőrgyógyászati betegségek hátterét keresve kerül sor. A szénhidrát-anyagcsere állapotának tisztázása, praediabetes vagy diabetes felismerésekor megfelelö kezelése, az elérhető legkedvezőbb anyagcsere-állapot biztosítása természetesen az optimális fogamzás elősegítésének integráns része. Ha azonban a cukorbetegség és előállapotai kizárásra kerültek, valamint a PCOS diagnosztikus feltételei [32] sem adottak, az IR külön vagy ismételt vizsgálata nem indokolt. Ugyanez a helyzet az elhízás eseteiben. A súlytöbblet csökkent inzulinhatással társul, a kezelést az IR mértéke nem, elsősorban a testtömeg nagysága befolyásolja.

Egyes megfigyelések szerint IR fennállásakor gyakoribbá válhat az első trimeszterben bekövetkező spontán 
abortuszok előfordulása, PCOS jelenléte nélkül is. Ilyenkor, különösen ismételt előfordulás esetén, felmerülhet az inzulinhatás vizsgálatának szükségessége. Más kérdés, hogy - IR igazolódásakor - a szénhidrát-anyagcsere dokumentálható károsodásának hiányában a várandósságot kívánó nő esetleges súlytöbbletének csökkentésére és az egészséges életmódra irányuló tanácsok, valamint - nem terhes állapotban - a túlsúly/elhízás gyógyszeres kezelése jelenti az egyedüli lehetőséget [33].

Ismételten fel kell hívnunk a figyelmet arra, hogy az IR esetleges fennállása vagy hiánya nem befolyásolja a mesterséges megtermékenyítés sikerét, és igazolódása önmagában nem magyarázza a meddőség hátterét [19].

Ha mégis felmerül, hogy bármely okból szükséges lehet az IR megerôsítése vagy kizárása, az esetek többségében elegendő a HOMA-IR meghatározása és - a mérőszám megadásához amúgy is elengedhetetlen - FPI mérése. Ha a glükóztolerancia, a praediabetes vagy a diabetes tisztázása is szükséges, OGTT végzendő, de a széruminzulinszint több időpontban történő vizsgálata felesleges. Költségnövelő, a vizsgált személyt és a vizsgálólaboratóriumot egyaránt terhelő. $\mathrm{A} \mathrm{HbA}_{\mathrm{lc}}$-vizsgálat a cukorbetegség felismerésében segíthet, de a hatályos hazai irányelv szerint a praediabetes kórismézésére ez idő szerint nem alkalmazható [23], az IR felismerésében pedig végképp nincs szerepe.

\section{Az inzulinrezisztencia kezelése}

Előre kell bocsátanunk, hogy önmagában az IR kezelésére az életmód-változtatáson - a lehetőség szerint napi gyakoriságú, a teherbíró képességhez igazodó intenzitású fizikai terhelésen („exercise”), az összetételében és energiatartalmában egyaránt a korszerú táplálkozási irányelveket követő étrenden és ezek eredményeként az esetleges túlsúly csökkentésén - túl más lehetőség ez idő szerint nem áll rendelkezésre.

Ha a csökkent inzulinhatás a szénhidrát-anyagcsere kimutatható károsodásával, praediabetesszel, vagy diabetesszel is társul, a fentiek mellett metformin is adható, illetve manifeszt cukorbetegségben, ha a kezelési célérték metformin önmagában történő alkalmazásával nem biztosítható, adása más vércukorcsökkentővel kombinálható.

Hazai gyakorlatunkban a metforminon kívül más antidiabetikum nincs törzskönyvezve a praediabetes kezelésére, a szénhidrát-anyagcsere károsodásával nem kísért IR gyógyszeres kezelésére pedig nincs ilyen indikációval alkalmazható készítmény.

Terjedelmi okok miatt részletes tárgyalásától el kell tekintenünk, de megemlítjük, hogy a metabolikus szindróma megítélése a korábbiakhoz képest napjainkban jelentősen módosult. Nem tekintjük önálló kórformának, sokkal inkább kockázati tényezők - túlsúly/elhízás, hypertonia, dyslipidaemia, diabetes stb. - együttes fennállása folytán fokozott keringési veszélyeztetettséget jel- ző állapotnak. Az elsődleges feladat e tényezők célzott keresése és hatékony, célértékre törő kezelésük minél korábbi megkezdése [34].

Anyagi támogatás: A cikk megírása anyagi támogatásban nem részesült.

A szerző a cikk végleges változatát elolvasta és jóváhagyta.

Érdekeltségek: A szerzőt a cikk megírásához anyagi érdekeltség nem füzi. Tanácsadó testületi tag az alábbi cégeknél: NovoNordisk Hungária Kft., AstraZeneca Kft. Esetenként szakértőként közremúködik a Wörwag Pharma Kft.-nél, a 77-Elekronika Kft.-nél és a Servier Hungária Kft.-nél.

\section{Irodalom}

[1] Winkler G, Cseh K. The meaning of insulin resistance. In: Winkler G, Wittmann I. (eds.) The insulin resistance and its clinical aspects. [Az inzulinrezisztencia fogalma. In: Winkler G, Wittmann I. (szerk.) Az inzulinrezisztencia és klinikai vonatkozásai.] SpringMed Kiadó, Budapest, 2017; pp. 25-28. [Hungarian]

[2] Winkler G, Cseh K. Molecular mechanisms of insulin resistance in obesity and type 2 diabetes mellitus. [Molekuláris tényezók szerepe az inzulinrezisztencia-elhízás-2-es típusú diabetes patogenetikai kapcsolatban.] Orv Hetil. 2009; 150: 771-780. [Hungarian]

[3] Borai A, Livingstone C, Ferns GA. The biochemical assessment of insulin resistance. Ann Clin Biochem. 2007; 44: 324-342.

[4] Malek R, Chong AY, Lupsa BC, et al. Treatment of type B insulin resistance: a novel approach to reduce insulin receptor antibodies. J Clin Endocrinol Metab. 2010; 95: 3641-3647.

[5] Baranyi É, Winkler G. Pregnancy and insulin resistance. In: Winkler G, Wittmann I. (eds.) The insulin resistance and its clinical aspects. [Terhesség és inzulinrezisztencia. In: Winkler G, Wittmann I. (szerk.) Az inzulinrezisztencia és klinikai vonatkozásai.] SpringMed Kiadó, Budapest, 2017; pp. 183-192. [Hungarian]

[6] Antunes LC, Elkfury JL, Jornada MN, et al. Validation of HOMA-IR in a model of insulin-resistance induced by a high-fat diet in Wistar rats. Arch Endocrinol Metab (Sao Paolo). 2016; 60: 138-143.

[7] Singh B, Saxena A. Surrogate markers of insulin resistance: a review. World J Diabetes 2010; 1: 36-47.

[8] Wallace TM, Levy JC, Matthews DR. Use and abuse of HOMA modeling. Diabetes Care 2004; 27: 1487-1495.

[9] Song YS, Hwang YC, Ahn HY, et al. Comparison of the usefulness of the updated homeostasis model assessment (HOMA2) with the original HOMAl in the prediction of type 2 diabetes mellitus in Koreans. Diabetes Metab J. 2016; 40: 318-325.

[10] Chang AM, Smith MJ, Bloem CJ, et al. Limitation of the homeostasis model assessment to predict insulin resistance and beta-cell dysfunction in older people. J Clin Endocrinol Metab. 2006; 91: 629-634.

[11] Munoz AJ, Lara-Castro C, Garvey WT. The HOMA index estimation of insulin resistance is affected by ethnicity. Abstract No. 1013-P. 68th Scientific Sessions of the American Diabetes Association, San Francisco, CA, 2008. Available from: https://professional.diabetes.org/abstract/homa-index-estimation-insulinresistance-affected-ethnicity [accessed: March 16, 2020]. 
[12] DeBoer MD, Dong L, Gurka MJ. Racial/ethnic and sex differences in the ability of metabolic syndrome criteria to predict elevations in fasting insulin in adolescents. J Pediatr. 2011; 159: 975-981.e3.

[13] Horáková D, Štěpánek L, Janout V, et al. Optimal homeostasis model assessment of insulin resistance (HOMA-IR) cut-offs: a cross-sectional study in the Czech population. Medicina (Kaunas) $2019 ; 55: 158$

[14] Singh Y, Garg MK, Tandon N, et al. A study of insulin resistance by HOMA-IR and its cut-off value to identify metabolic syndrome in urban Indian adolescents. J Clin Res Pediatr Endocrinol. 2013; 5: 245-251.

[15] Lee CH, Shih AZ, Woo YC, et al. Optimal cut-offs of homeostasis model assessment of insulin resistance (HOMA-IR) to identify dysglycemia and type 2 diabetes mellitus: a 15 -year prospective study in China. PLoS ONE 2016; 11: e0163424.

[16] Wongwananuruk T, Rattanachaiuyanont $M$, Leerasiri $P$, et al. The usefulness of homeostasis measurement assessment-insulin resistance (HOMA-IR) for detection of glucose intolerance in Thai women of reproductive age with polycystic ovary syndrome. Int J Endocrinol. 2012; 2012: 571035.

[17] De Azevedo Salgado AL, de Carvalho L, Oliveira AC, et al. Insulin resistance index (HOMA-IR) in the differentiation of patients with non-alcoholic fatty liver disease and healthy individuals. Arq Gastroenterol. 2010; 47: 165-169.

[18] Csákány MGy, Konc J. Personal information. [Csákány MGy, Konc J. Személyes közlés.] [Hungarian]

[19] Gursoy AF, Tokmak A, Eroğlu S, et al. Effect of insulin resistance on the occurrence of pregnancy in women treated empirically for unexplained infertility. Acta Endocrinol (Buc). 2017; 13: 314321.

[20] Mellerio H, Alberti C, Druet C, et al. Novel modeling of reference values of cardiovascular risk factors in children aged 7 to 20 years. Pediatrics 2012; 129: e1020-e1029.

[21] Aradillas-Garcia C, Rodríguez-Morán M, Garay-Sevilla ME, et al. Distribution of the homeostasis model assessment of insulin resistance in Mexican children and adolescents. Eur J Endocrinol. 2012; 166: 301-306.

[22] World Health Organization \& International Diabetes Federation. Definition and diagnosis of diabetes mellitus and intermediate hyperglycemia: report of a WHO/IDF consultation. WHO, Geneva, 2006. Available from: https://www.who.int/ diabetes/publications/Definition\%20and\%20diagnosis\%20 of\%20diabetes_new.pdf [accessed: March 16, 2020].

[23] Jermendy G. (ed.) Diagnosis of diabetes mellitus, treatment and care of diabetic patients in the adulthood. Professional guideline of the Hungarian Diabetes Association - 2014. [A diabetes mellitus kórismézése, a cukorbetegek kezelése és gondozása a felnőttkorban. A Magyar Diabetes Társaság szakmai irányelve 2014.] Diabetol Hung. 2014; 22(Suppl 1): 2-84. [Hungarian]
[24] Baranyi É, Winkler G. (eds.) Proposal for the recognition of glucometabolic disorders during pregnancy. Recommendations of the expert discussion from 06 October 2015 of the Pregnancy Study Group of the Hungarian Diabetes Society. [Javaslat a terhesség alatti glukózanyagcsere-zavarok felismerésére. A Magyar Diabetes Társaság (MDT) Diabétesszel Társuló Terhességgel Foglalkozó Munkacsoportja 2015. október 6-i kerekasztal-megbeszélésének ajánlásai. Diabetol Hung. 2016; 24: 85-88. [Hungarian]

[25] Buppajarntham S, Junpaparp P, Salameh R, et al. Insulin. Medscape. Last updated 09. 01. 2019. Available from: https:// emedicine.medscape.com/article/2089224-overview [accessed: March 16, 2020].

[26] Melmed S, Polansky KS, Larsen PS, et al. Williams textbook of endocrinology, 13th edition. Elsevier-Saunders, Philadelphia, PA, 2016.

[27] Borai A, Livingstone C, Kaddam I, et al. Selection of the appropriate method for the assessment of insulin resistance. BMC Med Res Methodol. 2011; 11: 158.

[28] Yan Y, Li S, Liu Y, et al. Temporal relationship between inflammation and insulin resistance and their joint effect on hyperglycemia: the Bogalusa Heart Study. Cardiovasc Diabetol. 2019; 18: 109 .

[29] Bachali S, Balantrapu P, Epari VR. High sensitive C-reactive protein, insulin resistance and coronary artery disease risk. Int J Biol Med Res. 2012; 3: 2570-2574.

[30] Olatunbosun ST. Insulin resistance clinical presentation. Medscape, updated 2019 Aug 7. Available from: https://emedicine. medscape.com/article/122501-clinical [accessed: March 16, 2020].

[31] Napolitano M, Megna M, Monfrecola G. Insulin resistance and skin diseases. Scientific World J. 2015; 2015: 479354.

[32] Teede HJ, Misso ML, Boyle JA, et al. Translation and implementation of the Australian-led PCOS guideline: clinical summary and translation resources from the International Evidence-based Guideline for the Assessment and Management of Polycystic Ovary Syndrome. Med J Aust. 2018; 209: S3-S8.

[33] Hong Y, Xie QX, Chen CY, et al. Insulin resistance in first trimester pregnant women with pre-pregnant glucose tolerance and history of recurrent spontaneous abortion. J Biol Regul Homeost Agents 2013; 27: 225-231.

[34] Ormazabal V, Nair S, Elfeky O, et al. Association between insulin resistance and the development of cardiovascular disease. Cardiovasc Diabetol. 2018; 17: 122.

(Winkler Gábor dr., Budapest, Diós árok 1-3., 1125 e-mail: gabor.winkler@janoskorhaz.hu)

A cikk a Creative Commons Attribution 4.0 International License (https://creativecommons.org/licenses/by/4.0/) feltételei szerint publikált Open Access közlemény, melynek szellemében a cikk bármilyen médiumban szabadon felhasználható, megosztható és újraközölhetö, feltéve, hogy az eredeti szerző és a közlés helye, illetve a CC License linkje és az esetlegesen végrehajtott módosítások feltüntetésre kerülnek. (SID_1) 